\title{
CHARACTERIZE OF PRODUCTION SYSTEMS AND MILK QUALITY OF PRODUCTION UNITS IN THE SEMIARID REGION OF CEARÁ
}

\section{CARACTERIZAÇÃO DOS SISTEMAS DE PRODUÇÃO E QUALIDADE DO LEITE DE UNIDADES PRODUTORAS NO SEMIÁRIDO DO CEARÁ}

\author{
Ângela Maria de Vasconcelos ${ }^{1}$ \\ Daniele Alves de Farias ${ }^{2}$ \\ Tereza Cristina Lacerta Gomes ${ }^{1}$ \\ Aline Vieira Landim ${ }^{1}$ \\ Robson Mateus Freitas Silveira ${ }^{1^{*}}$ \\ Thays Paulina Martins ${ }^{1}$

\begin{abstract}
${ }^{1}$ Universidade Estadual Vale do Acaraú - UVA, Campus Betânia, Sobral, Ceará, Brasil.
${ }^{2}$ Parte da dissertação da autora. Centro de Ensino Tecnológico (CENTEC) na Escola Estadual de Ensino Profissionalizante Guilherme Teles Gouveia, Granja, Ceará, Brasil.

${ }^{*}$ Correspondent author - robsonmateus1994@hotmail.com
\end{abstract}

\begin{abstract}
The aim of this study was to characterize the production systems and milk quality of eight milk production units (MPU) in the semiarid region of the state of Ceará, Brazil. Individual interviews were conducted through a questionnaire on the characteristics of the properties and production systems. Samples of milk and water were collected for a period of 12 months. Four MPUs were classified as semi-specialized and four as non-specialized. No differences were observed in milk composition between the two production systems, and both showed protein, fat, and solids-not-fat levels. Differences were observed for somatic cell count. The semi-specialized systems showed an average somatic cell and total bacterial count which is above the limit established by the 62nd Normative Instruction. All water samples showed presence of Escherichia coli. Somatic cell count was positively correlated (fat) and negatively (lactose). For total bacterial count, correlations were negative for fat, total solids, and somatic cell count. The microbiological quality of milk is not in accordance with the 62st and 7th Normative Instructions. The specialization of the production systems did not result in improved microbiological aspects of milk.
\end{abstract}

Keywords: Milk composition. Somatic cells. Total bacterial count

\section{Resumo}

O objetivo deste estudo foi caracterizar os sistemas de produção e a qualidade do leite de oito unidades de produção de leite (UPL) na região semiárida do estado do Ceará. Entrevistas individuais foram realizadas por meio de um questionário sobre as características das propriedades e sistemas de produção. Amostras de leite e água foram coletadas por um período de 12 meses. Quatro UPLs foram classificadas como semiespecializadas e quatro como não especializadas. Não foram observadas 
diferenças na composição do leite entre os dois sistemas de produção, e ambos apresentaram níveis de proteína, gordura e sólidos não gordurosos. Diferenças foram observadas para contagem de células somáticas. Os sistemas semiespecializados apresentaram contagem média de células somáticas e bacterianas totais acima do limite estabelecido pela $62^{\mathrm{a}}$ Instrução Normativa. Todas as amostras de água mostraram presença de Escherichia coli. A contagem de células somáticas foi correlacionada positivamente (gordura) e negativamente (lactose). Para contagem bacteriana total, as correlações foram negativas para gordura, sólidos totais e contagem de células somáticas. A qualidade microbiológica do leite não está de acordo com as Instruções Normativas $62^{\mathrm{a}}$ e $7^{\mathrm{a}}$. A especialização dos sistemas de produção não resultou em melhores aspectos microbiológicos do leite.

Palavras-chave: Composição do leite. Células somáticas. Contagem Bacteriana Total.

Received on: May, 08, 2018.

Accepted on: September, 17, 2018.

\section{Introduction}

The globalization of economy and the ever-growing competitiveness have reinforced the importance of economic efficiency for the good performance of the dairy activity in Brazil. To adapt to this new reality, the dairy sector in the northeast region of the country must adopt technologies to increase productivity and improve the quality of the milk product, which requires knowledge of the socioeconomic characteristics of the producer, of the property, and of production systems.

The production rates and the quality of milk produced in the northeast region of Brazil are still below those achieved in locations where the activity is regarded a reference. This is attributed to the profile of the producer and poor access to technical assistance; insufficient participation of public agencies for extension, including the (lack of) promotion of regional programs for the sanitary control of herds; and mainly the lack of dairy holdings that differentiate the milk price according to the product's quality ${ }^{(1)}$.

Consumers of animal products have been increasingly demanding in terms of price and quality. This trend has prompted important changes in the object of dairy production. In this scenario, a great part of dairy industries is already adopting the payment of milk for quality. This quality is related to the microbiological factor associated with hygiene during the milking process; the somatic cell count; and the nutrient composition of milk. The fat, the protein, and the solids-not-fat - termed 'total solids' - are the variables of major economic importance and thus constitute a criterion for the valuation of milk in many countries ${ }^{(2-3)}$

In Brazil, the first initiative aimed at standardizing and improving the milk quality was the implementation of national quality-standard norms determined by the National Program for the Improvement of Milk Quality of the Ministry of Agriculture, Livestock, and Supply and by Normative Instruction no. 51 (NI 51). This NI was revoked by Normative Instruction no 62 in December $2011^{(4)}$ and recently by the publication of Normative Instruction no. 7 of May $2016^{(5)}$, which postponed the deadlines and extended limits for total bacterial count and somatic cell count in the quality of cow milk. Considering that milk production in Ceará State has grown in the last few 
years, especially in the dairy network of Sobral ${ }^{(6)}$, and that the law must be abided by all milk producers, the present study was conducted to characterize milk production systems and the quality of milk in milk production units (MPUs) in Sobral - CE, Brazil.

\section{Material and Methods}

The present study was conducted at eight cow-milk production units in the municipality of Sobral $\mathrm{CE}$, Brazil, which is located in a semiarid environment typical of the Brazilian Northeast $\left(3^{\circ} 41^{\prime} \mathrm{S}\right.$ latitude, $40^{\circ} 20^{\prime} \mathrm{W}$ longitude, $69.49 \mathrm{~m}$ asl). The annual average temperature is 26 to $28^{\circ} \mathrm{C}$, and the rainy period is from January to May, with an average precipitation of $821.6 \mathrm{~mm}^{(7)}$. Dairy farms located in the districts of Patriarca and Caioca were studied over a year.

The characterization of MPUs was based upon an adapted methodology of Gonzalez et al. ${ }^{(8)}$. considering seven criteria for the classification into semi-specialized or non-specialized system (Table 1).

Table1. Characterization of production systems at cow-milk production units in Sobral - CE, Brazil

\begin{tabular}{|c|c|c|}
\hline \multirow{2}{*}{ Criterion } & \multicolumn{2}{|c|}{ Production system } \\
\hline & Semi-specialized & Not specialized \\
\hline $\begin{array}{l}\text { 1. Feeding management } \\
\text { (supplementation in the rainy and dry } \\
\text { periods) }\end{array}$ & Adoption & Non-adoption \\
\hline 2. Early weaning of calves* & Adoption & Non-adoption \\
\hline \multirow{2}{*}{$\begin{array}{l}\text { 3. Reproduction management } \\
\text { (Artificial insemination/natural service) }\end{array}$} & Adoption & Non-adoption \\
\hline & $\begin{array}{l}\text { Predominance of } \\
\text { Girolando cows }\end{array}$ & $\begin{array}{l}\text { Predominance of } \\
\text { crossbred cows }\end{array}$ \\
\hline 4. Breed types & $\begin{array}{l}\text { Predominance of } \\
\text { specialized sires } \\
\text { (Holstein and/or } \\
\text { Gyr) }\end{array}$ & $\begin{array}{l}\text { No predominance of } \\
\text { specialized sires }\end{array}$ \\
\hline 5. Milking system & Mechanical & $\begin{array}{l}\text { Manual (presence of } \\
\text { the calf on foot) }\end{array}$ \\
\hline $\begin{array}{l}\text { 6. Sanitary management of milking } \\
\text { (mastitis control measures) }\end{array}$ & Adoption & $\begin{array}{l}\text { Basic measures or } \\
\text { non-adoption }\end{array}$ \\
\hline 7. Zootechnical notations & Full adoption & $\begin{array}{l}\text { Partial or non- } \\
\text { adoption }\end{array}$ \\
\hline
\end{tabular}

* At approximately three months of age.

The primary data that enabled the characterization of the production systems were obtained through the application of an adapted questionnaire of Gomes ${ }^{(9)}$ in individual interviews.

At each MPU, in both types of production system evaluated, eight milk samples were collected monthly over a period of 12 months, totaling 96 samples of raw milk. Of this total, 48 samples corresponded to the semi-specialized system and 48 to the non-specialized system. Thirty-two 
samples were collected from each system for analyses of composition and somatic cell count (SCC) and 16 samples for total bacterial count (TBC). Milk samples of approximately $80 \mathrm{~mL}$ were collected at each MPU directly from the brass vessel that was previously agitated for approximately seven seconds with a ladle-like collector. Samples were packed in identified plastic jars to which Bronopol preservative pills were added for the analyses of composition and SCC, or Azidiol pills for TBC, following the procedures described by Brito ${ }^{(10)}$. Next, the milk samples were homogenized until complete dissolution of the pills and then placed in an isothermal box with ice and sent to one of the accredited laboratories of the Brazilian Milk Quality Network (Federal Rural University of Pernambuco). In the laboratory, samples were analyzed for the centesimal composition of fat, protein, lactose, total solids, and solids-not-fat using the absorption spectrometry technique in the midinfrared region (MID); and for determination of SCC and TBC by flow cytometry.

We also collected samples of water from each property that was used for consumption and cleaning the animals as well as for washing utensils and milking equipment. The water was collected in ambercolored sterilized glass bottles with $1 \mathrm{~L}$ capacity and immediately sent for the Laboratory of Water Analysis. Upon arrival, samples were analyzed for the most probable number (MPN) of thermotolerant coliforms (TTC) or Eschericia coli, by the of multiple-tube fermentation technique ${ }^{(11)}$.

A completely randomized experimental design was adopted in which the production systems were considered the treatments. The dependent variables referring to the milk quality were percentages of fat, protein, lactose, total solids, and solids-not-fat, somatic cell count, and total bacterial count.

The data were subjected to the Shapiro-Wilk test to check the normality assumption. The existence of possible outliers (values too distant from the others) was determined, revealing the values of 12.36, 6.88 , and 15.66 for fat and 14.6, 20.2, 14.5, and 23.7 for total solids, which were removed from the analysis. Of the seven dependent (response) variables, only those pertaining to fat and SCC did not meet the normality assumption. Thus, the following respective transformations were applied to normalize them: $y_{1}=1 / y_{1}$ and $y_{2}=\log \left(y_{2}\right)$. Subsequently, the $\mathrm{F}$ test was performed via analysis of variance (ANOVA), considering the following models: $y_{i k}=\mu+S_{i}+\varepsilon_{i k}$, where $y_{i k}$ is the dependent variable; $\mu$ is the overall mean; $S_{i}$ is the effect of the production system (i=1- semi-specialized; 2 - non-specialized); and $\varepsilon_{i k}$ is the effect of the residual random error. When significances were detected in the ANOVA, the pairs of means were compared by Tukey's test at the $5 \%$ significance level.

The statistical software used for the analyses was SAS version $9.2^{(12)}$

\section{Results and Discussion}

None of the studied MPUs showed the seven defined characteristics to classify the production systems (Table 1). Therefore, each system was classified into the type for which it showed at least five characteristics (Table 2).

Of the four MPUs classified as non-specialized (NS) (Table 2), the feeding management with inclusion of concentrate supply during the year was observed in only two of them. In the others, the animals were freed during the rainy period and consumed only native pasture without concentrate 
supplementation. As for the management of the calves, in all MUPs, weaning occurred naturally at around eight months of age. The use of artificial insemination in this system was observed on two farms, while the others used natural service, on the field. The predominance of crossbred cows (three properties) and the variation in the breed pattern of the sires might have interfered with the reduction of reproductive and productive indices due to the longer calving interval, delayed age at first service, and lower volume of milk produced.

Table 2. Characterization of cow milk production units in each production system (semispecialized and non-specialized)

\begin{tabular}{llll}
\hline \multicolumn{1}{c}{ Production system } & n & \multicolumn{1}{c}{ Production system } & n \\
\hline Concentrate-based feeding over the & 4 & \multicolumn{1}{c}{ Non-specialized } & $\mathbf{4}$ \\
year & 4 & Concentrate-based feeding over the & 2 \\
Early weaning & 4 & year & 0 \\
Artificial insemination & 2 & Arly weaning & 2 \\
Crossbred cows & 3 & Crossbred cows & 3 \\
Holstein sire; Gyr sire & $4 ; 3$ & Holstein sire; Gyr sire & $3 ; 1$ \\
Mechanical milking & 2 & Mechanical milking & 4 \\
Manual milking with calf at foot & 4 & Manual milking with calf at foot & 0 \\
Two milking sessions per day & 4 & Two milking sessions per day & 3 \\
Strip-cup test and CMT & 4 & Strip-cup test and CMT & 2 \\
Cleaning of udder and teats & 4 & Cleaning of udder and teats & 1 \\
Pre-dipping & 3 & Pre-dipping & 0 \\
Basic zootechnical notations & 4 & Basic zootechnical notations & 3 \\
\hline Milk yield between 301 and $500 \mathrm{~L}$ & & Milk yield between 51 and $300 \mathrm{~L}$ & \\
Use of 76 to 100\% of the total area & & Use of 26 to 50\% of the total area & \\
\hline
\end{tabular}

Mechanical milking was not employed on any of the properties classified as NS. Manual milking was adopted in all of them, with the presence of the calves and two daily milking sessions predominating. Only two MPUs performed the control and prevention of mastitis by the strip-cup test and the California Mastitis Test (CMT), though irregularly. Only one farm cleaned the udder and teats by washing them with running water, and no pre- or post-dipping was practiced on any of the properties.

Basic zootechnical notations were made on three farms; only one of them showed no type of record. The traditionalism in the NS system was expressed by the adoption of manual milking with the calf at foot. Lack of interest in preventing mastitis was observed by the fact that most do not clean the udder, only setting the calf to suckle before milking was started. The characteristics that indicated low technological levels were reflected on the production scale (51 to $300 \mathrm{~L} /$ day), which might have been influenced by the lower use of the total area of the property for dairy farming ( 26 to $50 \%$ of the properties' areas).

In the four MPUs classified as semi-specialized (SS), the feeding management included the administration of concentrates during an entire year for lactating cows. The calf suckling period was approximately until three months of age.

Artificial insemination was used on two properties, which suggests the intention of using technology for the genetic breeding of the herd and for increasing the population. There was a predominance of Girolando crossbred cows (three farms) and specialized sires such as Holstein and Gyr. 
Mechanized milking was adopted in two MPUs and two daily sessions were carried out in all of them. Attention to or care with the heath of the cow, quality of milk, and adoption of sanitary measurements during milking such as the strip-cup test, the CMT test, and the cleaning of udder and teats with running water were present on all farms. Only one of them did not perform pre- or post-dripping.

The basic zootechnical notations performed by all producers of the MPUs classified as SS revealed a concern with maintaining the control of the herd. The dairy production scale ranging from 301 to more than $500 \mathrm{~L}$ of milk might have been influenced by the adoption of technologies coupled with greater use of the total area of the property (between 76 and 100\%) for dairy farming (Table 2).

Considering all the properties in both production systems, we observed low adoption of technology in general, in addition to inadequate sanitary management during milking in some of them. Neves et al. ${ }^{(13)}$ noted that the milking machine is not common equipment and that most part of producers milk the cows manually and only once daily, without any cleaning procedures.

In order for the milk quality to be improved, investments should be made in the awareness and training of personnel aiming to improve the hygienic conditions in production, adequate cleanliness of utensils and equipment, and storage and refrigeration of milk $^{(14)}$.

Despite being characterized by more adequate management practices (Table 2), the SS system did not show differences $(\mathrm{P}>0.05)$ in terms of milk composition (Table 3 ) when compared with the nonspecialized system.

Table 3. Fat, protein, lactose, total solids (TS), and solids-not-fat (SNF) contents of milk in different milk production units in Sobral - CE, Brazil, and minimum limits established by the $62^{\text {nd }}$ Normative Instruction (NI 62)

\begin{tabular}{|c|c|c|c|c|c|}
\hline \multirow[b]{2}{*}{ Variable } & \multicolumn{2}{|c|}{ Production system } & \multirow[b]{2}{*}{$\begin{array}{l}\text { Standard } \\
\text { error }\end{array}$} & \multirow[b]{2}{*}{ CV (\%) } & \multirow[b]{2}{*}{$\begin{array}{c}\text { NI } \\
62 / 2011\end{array}$} \\
\hline & Semi-specialized & $\begin{array}{c}\text { Non- } \\
\text { specialized }\end{array}$ & & & \\
\hline Fat (\%) & $3.43^{\mathrm{a}}$ & $3.25^{\mathrm{a}}$ & 0.07 & 19.09 & 3.00 \\
\hline Protein (\%) & $3.08^{\mathrm{a}}$ & $3.02^{\mathrm{a}}$ & 0.02 & 7.62 & 2.90 \\
\hline Lactose (\%) & $4.42^{\mathrm{a}}$ & $4.39^{n}$ & 0.02 & 4.64 & - \\
\hline TS (\%) & $11.93^{a}$ & $11.54^{a}$ & 0.08 & 6.19 & - \\
\hline SNF (\%) & $8.41^{\mathrm{a}}$ & $8.33^{\mathrm{a}}$ & 0.04 & 4.08 & 8.40 \\
\hline
\end{tabular}

a Means followed by common letters do not differ at the 0.05 significance level according to lukey's test. $C \mathrm{~V}=$ Cocfficient of variation

The results corroborate those found by Martins et al. ${ }^{(15)}$, who did not detect differences between the specialized and non-specialized systems for fat (3.06 and 3.21\%), protein (4.40 and 4.22\%), lactose (3.04 and 3.11\%), total solids (11.43 and 11.45\%), and solids-not-fat (8.37 and 8.23\%). However, they differ from those presented by Gonzalez et al. ${ }^{(8)}$ and Zanela et al. ${ }^{(16)}$, who observed differences between the systems for these variables.

In the SS system, two properties did not supplement their animals during the rainy period. According to Gonzalez et al. ${ }^{(8)}$, the difference between systems is due to the better nutritional conditions that result in larger milk production and consequently better centesimal composition thereof.

A comparison between the protein, fat, and solids-not-fat values found here (Table 3) with those established in Normative Instruction no. $62^{(4)}$ revealed that the two evaluated systems had samples within the standards for the minimum concentrations required. However, Zanela et al. ${ }^{(16)}$ suggested 
that regional characteristics should be considered in the establishment of milk composition standards. The authors found that because they provide better feeding conditions and use animals with a greater production potential, specialized and semi-specialized systems present higher percentages of samples with protein, fat, and solids-not-fat contents than those required by NI 62 in relation to the nonspecialized system.

Differences were observed $(\mathrm{P}<0.05)$ for $\mathrm{SCC}$, whereas TBC did not differ $(\mathrm{P}>0.05)$ between the systems (Table 4).

Table 4. Somatic cell count (SCC) and total bacterial count (TBC) of milk from different milk production units in Sobral - CE, Brazil, and maximum limits established by the 62 nd Normative Instruction (NI62) for the northeast region of the country

\begin{tabular}{|c|c|c|c|c|c|}
\hline \multirow{2}{*}{ Variable } & \multicolumn{2}{|c|}{ Production system } & \multirow{2}{*}{ Standard error } & \multirow{2}{*}{ CV $(\%)$} & \multirow{2}{*}{ NI 62/2011 } \\
\hline & SS & NS & & & \\
\hline $\operatorname{SCC}\left(10^{3}\right.$ cells $\left.\mathrm{mL}^{-1}\right)$ & $1.003^{\mathrm{a}}$ & $605^{b}$ & 116.76 & 140.44 & 100,000 \\
\hline $\mathrm{TBC}\left(10^{3} \mathrm{CFU} \mathrm{mL} \mathrm{L}^{-1}\right)$ & $3.276^{n}$ & $2.754^{n}$ & 253.90 & 73.80 & 400,000 \\
\hline
\end{tabular}

a,b Means followed by common letters do not differ at the 0.05 signiticance level according to Tukey's test.

Although a higher technological level was observed in the SS system, SCC was higher $(1.003,000$ cells $/ \mathrm{mL})$ than in NS $(605,000$ cells $/ \mathrm{mL})$, which does not use mastitis prevention measures or mechanical milking equipment (Table 2). This result reinforces the idea that the introduction of new technologies does not ensure an improvement in milk quality, and the implementation of good milking and recommendations regarding the treatment of mastitis and the maintenance and hygiene of milking equipment ${ }^{(17)}$. These findings differ from those reported by Martins et al. ${ }^{(15)}$ and Zanela et al. ${ }^{(16)}$ in the state of Rio Grande do Sul. These authors found respective mean values of 250,000 and 375,000 cells $/ \mathrm{mL}$ in the semi-specialized system and 568,000 and 803,000 cells $/ \mathrm{mL}$ in the nonspecialized system.

Although TBC did not differ between the systems, the higher means for the semi-specialized system may also indicate incidence of subclinical mastitis. This is possibly related to poor cleaning of the machinery used for milking; use of mechanical milking machine with probable presence of cracks on the rubber part; or the inadequate state of liners, which facilitates the spread of microorganisms in the milk after milking. Therefore, to reduce the bacterial count, sanitary measures employed in the milking process and in the storage of the milk should be improved; additionally, high-quality water should be used for this process. Guerreiro et al. ${ }^{(18)}$ observed a relatively high milk bacterial contamination index of 3.500,500 CFU/mL on farms adopting mechanical milking, which is higher than the value observed on farms where cows are milked manually $(300,000 \mathrm{CFU} / \mathrm{mL})$.

Based on the high total bacterium rates and somatic cell counts, we can state that there were losses in quality and quantity of produced milk that generated economic losses to the producer.

The SS system showed mean SCC values of 1.003,000 cells $/ \mathrm{mL}$ and TBC of 3.276,000 CFU/mL, which are above the limits established by the normative instructions. In the NS system, SCC $(605,000$ cells $/ \mathrm{mL}$ ) was also above the acceptable limits for producers to adequate until the deadline of July 2019 (Normative Instructions no. 62/2011 and 7/2016), for the northeast region(4-5). The total bacterial count $(2.754,000 \mathrm{CFU} / \mathrm{mL})$ was higher than the established limit (Table 4). In similar studies, values also higher than the established standards were found ${ }^{(19)}$. However, Zanela et al. ${ }^{(16)}$ 
demonstrated that the majority $(94.5 \%)$ of specialized, semi-specialized, and non-specialized production systems evaluated by them were below the maximum initially established limited of one million cells per milliliter.

Presence of Escherichia coli was observed in the water of the eight properties, with mean MPN values of $87 / 100 \mathrm{~mL}$ for the SS system and 17/100 mL for NS, ranging from 0.4 to 240 (Table 5).

Table 5. Most probable number (MPN) of thermotolerant coliforms (TTC) or Escherichia coli in the water in the different production systems of Sobral - CE, Brazil

\begin{tabular}{lccccc}
\hline \multirow{2}{*}{ Production system } & \multicolumn{5}{c}{ MPN of TTC/100 mL } \\
\cline { 2 - 5 } & Farm 1 & Farm 2 & Farm 3 & Farm 4 & \multirow{2}{*}{ Mean } \\
\hline Semi-specialized & 1.5 & $2.4 \times 10^{2}$ & $1.1 \times 10^{2}$ & 0.4 & $8.7 \times 10$ \\
Non-specialized & $2.4 \times 10$ & $1.5 \times 10$ & $1.5 \times 10$ & $1.5 \times 10$ & $1.7 \times 10$ \\
\hline
\end{tabular}

According to the potability standards, the acceptable parameters for the characteristics of the water supplied to the animals and used in the cleaning of machinery correspond to class-3 freshwater, which allows for a most probable number of Escherichia coli of up to $1,000 / 100 \mathrm{~mL}^{(20)}$. The analyzed water is thus in conformity with the Resolution on all evaluated properties. However, all analyzed samples disagree with Ordinance no. 1469 of December 9, 2000, which establishes the procedures and responsibilities related to the control and vigilance of water quality and its potability standard and determines that zero Escherichia coli or thermotolerant coliforms must be detected in $100 \mathrm{~mL}$ of water (21).

We verified that in the different production systems studied, the water used to feed the animals and for the procedures of milking, cleaning of utensils and equipment, and storage of milk is in conformity with the established microbiological standards ${ }^{(21)}$. Although the observed levels may not compromise the health of the animals, there is a risk for contamination of the milk that justifies the need for applying measures for the control and prevention of contamination and monitoring the water on rural properties.

Escherichia coli is one of the environmental agents that can be found in the water and lead to mastitis. If the final wash of the equipment is performed with water containing these microorganisms, the entire system can be contaminated ${ }^{(22)}$. Deficient sanitary practices associated with the use of lowquality water lead to contamination of the produced milk.

Correlations (Table 6) were of medium to high magnitude and positive between TS and fat (0.827) and protein (0.574). With respect to SNF, high and positive correlations were obtained with protein (0.685) and lactose (0.641). The SCC variable showed a medium and positive correlation with fat $(0.492)$ and a medium and negative correlation with lactose $(-0.571)$. For TBC, correlations were low and negative with fat $(-0.275)$, TS $(-0.250)$, and SCC $(-0.227)$.

The greater variability observed in this study for the fat component directly affected the total solids content, which is influenced by an increase in each chemical component of milk; these two variables were positively correlated $(0.827)$. This confirms that variations in total solids are directly related to changes in fat content. The present results were similar to those published by Gonzalez et al. ${ }^{(8)}$, who also reported a positive correlation between these two variables $(0.895)$. 
Table 6. Pearson correlations among the milk composition and microbiological quality variables in milk production units in Sobral - CE, Brazil

\begin{tabular}{lcccccc}
\hline & Fat & Protein & Lactose & TS & SNF & SCC \\
\hline Protein & $0.405^{* * *}$ & & & & & \\
Lactose & $-0.291^{* *}$ & $0.003 \mathrm{~ns}$ & & & & \\
TS & $0.827^{* * *}$ & $0.574^{* * *}$ & $-0.054 \mathrm{~ns}$ & & & \\
SNF & $0.053 \mathrm{~ns}$ & $0.685^{* * *}$ & $0.641^{* * *}$ & $0.497^{*}$ & & \\
SCC & $0.492^{* * *}$ & $0.093 \mathrm{~ns}$ & $-0.571^{* * *}$ & $0.362^{* *}$ & $-0.283^{* *}$ & \\
TBC & $-0.275^{*}$ & $0.083 \mathrm{~ns}$ & $0.080 \mathrm{~ns}$ & $-0.250^{*}$ & $0.138 \mathrm{~ns}$ & $-0.227^{*}$ \\
\hline
\end{tabular}

TS - total solids; SNF - solids-not-fat; SCC - somatic cell count; TBC - total bacterial count.

${ }^{*}$ significant at $5 \%(\mathrm{P}<0.05)$; ${ }^{* *}$ significant at $1 \%(\mathrm{P}<0.01)$; ${ }^{* * *}$ significant at $0.01 \%(\mathrm{P}<0.001)$; ns= not significant.

Protein was not negatively correlated with any variable. The increase in its concentration influenced the total solids contents.

Lactose was the milk component that showed the smallest variation, which is related to the regulation of osmotic pressure in the mammary gland. In healthy cows, higher lactose production determines larger milk production due to the reduction of losses to blood ${ }^{(23)}$. In this study, the increased lactose production promoted the occurrence of a higher solids-not-fat content.

The increased number of somatic cells in milk leads to alterations in the three main components: fat, protein, and lactose ${ }^{(17)}$. In this study, SCC influenced the milk fat contents $(0.492)$, such that as SCC increased, the fat concentration increased as well, while lactose production decreased $(-0.571)$. Rangel et al. ${ }^{(23)}$ found positive correlations of $0.510,0.457$, and 0.354 between SCC and fat, solidsnot-fat, and lactose, respectively.

Increased fat content as influenced by the increase in SCC was also found by Noro et al. ${ }^{(24)}$ and Cunha et al. ${ }^{(25)}$. Increased fat can be explained by the decline in milk production when the mammary gland is infected.

In this study, no correlations were found between SCC and protein. However, Noro et al. ${ }^{(24)}$ and Cunha et al. ${ }^{(25)}$ observed an elevation in protein content. The increase in milk protein might be due to an increase in cell protein and changes in the permeability of the infected mammary alveolar membrane ${ }^{(26)}$. Despite the increase in protein content, there is a reduction in the percentage of casein and an elevation in the percentage of serum proteins ${ }^{(17)}$. For these reasons, some dairy industries have used systems that adopt bonuses or penalties to stimulate the production of milk with low somatic cell counts.

Reduced lactose production stemming from the increase in SCC was observed in this study. Changes occur in the lactose contents because the infected mammary epithelium exhibits reduced lactosesynthesizing ability due to the use of lactose by the pathogenic microorganisms and due to the loss to the bloodstream resulting from the increased membrane permeability ${ }^{(27)}$. A negative correlation between lactose and somatic cell count was also observed by González et al. ${ }^{(8)}$, Machado et al. ${ }^{(27)}$, 
Noro et al. ${ }^{(24),}$ and Zanela et al. ${ }^{(16)}$.

Total solids were affected by the increase in SCC, agreeing with Machado et al ${ }^{(27)}$. These authors found a downward trend in percentage of total solids associated with an increase in somatic cell count. Silva et al. ${ }^{(28)}$, on the other hand, observed no significant correlations between the concentration of TS and SCC.

The bacterial count of raw milk helps in the evaluation of the milking process and storage procedures on the rural property. It also makes it possible to understand the likely negative effects on the industrial yield and the safety regarding the food quality of milk. In this study, TBC had a negative and low correlation with fat $(-0.275)$, total solids $(-0.250)$, and SCC $(-0.227)$. No significant correlations were found with protein, lactose, or SNF, however.

The alterations generated by the presence of bacteria in milk lead to a lower use of the product as raw material and compromise its organoleptic properties. Bueno et al. ${ }^{(29)}$ found that an increase in bacterial concentration provided a significant reduction only in the lactose content and an increase in protein content, whereas the fat and total solids levels did not show significant alterations.

As for the correlation between somatic cell count and total bacterial count, it is known that an increase in SCC is directly related to an increase in TBC in the udder. Therefore, in this study, the poor hygiene during milking is evidenced by the low correlation between TBC and SCC $(-0.227)$. This is explained by the fact that the milk samples were collected directly from the vessels rather than from the animals individually. Results might have thus been compromised due to problems of contamination of the milk collected from healthy animals, with an influence of the external environment; i.e., microbial contamination of the milk after milking caused by either poor hygiene or by contact with milk from contaminated animals. The water used for the milking procedures might have also influenced the results. As stated by Maciel et al. ${ }^{(19)}$, the use of non-potable water is a factor that may contribute to the contamination of milk.

\section{Conclusion}

It was observed in the study region that the improved production system did not adopt hygienic measures to obtain milk, and consequently did not reach the microbiological parameters established by MAPA. This demonstrates that the health of the mammary gland, hygiene during the milking process and milk cooling are important tools to achieve milk quality standards, regardless of the production system.

\section{References}

1. Silveira RMF, Vasconcelos AM, Araújo JM, Ferreira JB, Oliveira PGA, Brito TM. Influência dos índices reprodutivos na produção leite de vacas mestiças criadas no litoral Cearense. Agropecuária Cientifica do Semiárido [Internet]. 2018 [cited 2018 agosto 11]; 14 (2):117-122. Available from: DOI: http://dx.doi.org/10.30969/acsa.v14i2.938. Portuguese.

2. Pereira MA, Pérez JRO, Teixeira JC, Abreu, LR de, Muniz JA. Influência da fonte de proteína da dieta total na composição do leite de vacas holandesas. Ciência e Agrotecnologia [Internet]. 2001 [cited 2018 maio 
05];25(6):1446-1456 Available from: file://C:/Users/robso/Downloads/25-6-2001 22\%20(2).pdf Portuguese.

3. Tsenkova, R, Atanassova S, Kawano S, Toyoda K. Somatic cell count determination incow's milk by nearinfrared spectroscopy: a new diagnostic tool. Journal of Animal Science [Internet]. 2001 [cited 2018 maio 05];79(10):2550-2557.Available from: https://doi.org/10.2527/2001.79102550x . English

4. Brasil. Ministério da Agricultura, Pecuária e Abastecimento - MAPA. Instrução Normativa $n^{\circ} 62$, de 22 de dezembro de 2011 [acesso 20 Jul 2017]. Availaible from: http://www.apcbrh.com.br/files/IN62.pdf

5. Brasil. Ministério da Agricultura, Pecuária e do Abastecimento. Instrução Normativa $n^{0} 07$ de 03 de maio de 2016. Diário Oficial da União. 2016 Mai 04. Seção 1. Availaible from: https://www.lex.com.br/legis_27130719_INSTRUCAO_NORMATIVA_N_7_DE 3 DE_MAIO_DE_2016. aspx Portuguese

6. Magalhães KA, Campos RT. Eficiência Técnica e Desempenho Econômico de Produtores de Leite no Estado do Ceará, Brasil. Revista de Economia e Sociologia Rural. 2006 Out/Dez [cited 2018 maio 05];44(4):695-711. Availaible from: http://dx.doi.org/10.1590/S0103-20032006000400004. Portuguese.

7. Instituto de Pesquisa e Estratégia Econômica do Ceará. IPECE. Perfil Básico Municipal. 2009. Disponível em: http://www.ipece.ce.gov.br Acesso em: 10/jan/10. Portuguese

8. Gonzalez HL, Fischer V, Ribeiro MER, Júnior WS, Gomes JF, Fagundes CM, Silva MA. Comparação da qualidade do leite em diferentes sistemas de produção da bacia leiteira de Pelotas, RS. Revista Brasileira de Agrociência [Internet]. 2006 Out/Dez [cited 2017 Nov 6];12(4):475-482. Availaible from: http://www2.ufpel.edu.br/faem/agrociencia/v12n4/artigo15.pdf. Portuguese.

9. Gomes TCL. Aglomerações Produtivas e Desenvolvimento Local: arranjos produtivos locais de amêndoa da castanha-de-caju nos municípios de Barreira e Pacajus no Estado do Ceará [dissertação]. [Porto Alegre]: Universidade Federal do Rio Grande do Sul; 2007. 274 p. Availaible from: http://www.lume.ufrgs.br/bitstream/handle/10183/28728/000602708.pdf?sequence=1. Portuguese.

10. Brito JRF. Coleta de amostras de leite para determinação da composição química e contagem de células somáticas. Juiz de Fora: Embrapa Gado de Leite. 2011. (Circular Técnica 62). Portuguese

11. Blodgett, R. Appendix 2: most probable number from serial dilutions. In: Food and Drug Administration - FDA. Bacteriological Analytical Manual on line. FDA/CFSAN, 2001. Disponível em: www.cfsan.fda.gov/ ebam/bam-a2.html. Acesso em: 13 mai. 2017.

12. SAS Institute. Statistical Analysis System: user guide [CD-ROM]. Version 6.08. Cary: SAS Insitute Inc.; 1997. English.

13. Neves ALA. Pereira LGR, Santos RD, Araújo GGL, Carneiro AV, Moraes SA, Spaniol CMO, Aragão ASL. Caracterização dos produtores e dos sistemas de produção de leite no perímetro irrigado de Petrolina/PE. Revista Brasileira de Saúde e Produção Animal [Internet]. 2011 Jan/Mar [cited 2017 Nov 6];12(1):209-223. Availaible from: http://revistas.ufba.br/index.php/rbspa/article/view/1843/1075. Portuguese.

14. Citadin AS, Pozza MSS, Pozza PC, Nunes RV, Borsatti L, Mangoni J. Qualidade microbiológica de leite cru refrigerado e fatores associados. Revista Brasileira de Saúde e Produção Animal [Internet]. 2009 Jan/Mar [cited 2018 maio 05]; 10(1):52-59. Availaible from: http://revistas.ufba.br/index.php/rbspa/article/view/943/762. Portuguese.

15. Martins PRG, Fischer V, Ribeiro MER, Gomes JF, Junior WS, Zanela MB. Produção e qualidade do leite em sistemas de produção da região leiteira de Pelotas, RS, Brasil. Ciência Rural [Internet]. 2007 Jan/Fev [cited 2018 maio 05];37(1):212-217. Availaible from: http://www.scielo.br/pdf/\%0D/cr/v37n1/a34v37n1.pdf. Portuguese. 
16. Zanela MB, Fischer V, Ribeiro MER, Junior WS, Zanela C, Marques LT, Martins PRG. Qualidade do leite em sistemas de produção na região sul do Rio Grande do Sul. Pesquisa Agropecuária Brasileira [Internet]. 2006 Jan [cited2018 maio 05];41(1):153-159. Availaible from: http://www.scielo.br/pdf/\%0D/pab/v41n1/28153.pdf. Portuguese.

17. Silva JC and Antunes RC. Effect of type of milking and environment on the raw milk quality based on somatic cells count. Ciência Animal Brasileira [Internet]. 2018 Oct [cited 2018 september 14];19: 1-16. DOI: 10.1590/1809-6891v19e-34635. Portuguese

18. Guerreiro KP, Machado MRF, Braga GC, Gasparino E, Franzener ASM. Qualidade microbiológica de leite em função de técnicas profiláticas no manejo de produção. Ciência e Agrotecnologia [Internet]. 2005 Jan/Fev [cited 2017 Nov 6];29(1):216-222. Availaible from: http://www.scielo.br/pdf/cagro/v29n1/a27.pdf. Portuguese.

19. Maciel JF, Carvalho EA, Santos LS, Araújo JB, Nunes VS. Qualidade microbiológica do leite cru comercializado em Itapetinga. Revista Brasileira de Saúde e Produção Animal [Internet]. 2008 Jul/Set [cited 2017 Nov 6];9(3):443-448. Availaible from: http://revistas.ufba.br/index.php/rbspa/article/view/849/665. Portuguese.

20. Brasil. Ministério do Meio Ambiente. Conselho Nacional do Meio Ambiente. Resolução no 357 , de 17 de março de 2005. Dispõe sobre a classificação dos corpos de água e diretrizes ambientais para o seu enquadramento, bem como estabelece as condições e padrões de lançamento de efluentes, e dá outras providências. Diário Oficial da União. 2005 Mar 03. Availaible from: http://www.mma.gov.br/port/conama/res/res05/res35705.pdf. Portuguese

21. Brasil. Ministério da Saúde. Portaria $n^{\circ}$ 1469, de 29 dezembro de 2000. Norma de Qualidade da água para consumo humano. Diário Oficial da União. 2001 Jan 10. Availaible from: http://www.agenciapcj.org.br/docs/portarias/portaria-ms-1469-00.pdf Portuguese

22. Lagger JR, Mata HT, Pechin GH, Larrea AT, Otrosky RN, Cesan RO, Caimier AG, Meglia, GE. La importancia de la calidad del agua en producción lechera. Veterinaria Argentina [Internet]. 2000 [cited 2017 Nov 6];17(165):346-354. Availaible from: < http://www.produccion-animal.com.ar/agua bebida/32 calidad_agua en produccion_lechera.pdf $>$. Spanish.

23. Rangel AHN, Medeiros HR, Silva JBA, Barreto MLJ, Lima Júnior DM. Correlação entre a contagem de células somáticas (CCS) e o teor de gordura, proteína, lactose e extrato seco desengordurado do leite. Revista Verde [Internet]. $2009 \mathrm{Jul} / \mathrm{Set}$ [cited 2017 Nov 6];4(3):57-60. Availaible from: http://www.gvaa.com.br/revista/index.php/RVADS/article/view/197/197. Portuguese.

24. Noro G, González FHD, Campos R, Dürr JW. Fatores ambientais que afetam a produção e a composição do leite em rebanhos assistidos por cooperativas no Rio Grande do Sul. Revista Brasileira de Zootecnia [Internet]. 2006 Mai/Jun [cited 2017 Nov 6];35(3):1129-1135. Availaible from: http://dx.doi.org/10.1590/S1516-35982006000400026. Portuguese.

25. Cunha RPL, Molina LR, Carvalho AU, Facury Filho EJ, Ferreira PM, Gentilini MB. Mastite subclínica e relação da contagem de células somáticas com número de lactações, produção e composição química do leite em vacas de raça Holandesa. Arquivo Brasileiro de Medicina Veterinária e Zootecnia [Internet]. 2008 Fev [cited 2017 Nov 6];60(1):19-24. Availaible from: http://dx.doi.org/10.1590/S0102-09352008000100003. Portuguese.

26. Pereira AR, Silvia LFP, Molon LK, Machado PF, Barancelli G. Efeito do nível de células somáticas sobre os constituintes do leite I - Gordura e proteína. Revista Brasileira de Pesquisa Veterinária e Ciência Animal [Internet]. 1999 [cited 2017 Nov 6]; 36(3):121-124. Availaible from: https://www.revistas.usp.br/bjvras/article/view/5754/64777. Portuguese. 
27. Machado PF, Pereira AR, Sarríe GA. Composição do Leite de Tanques de Rebanhos Brasileiros Distribuídos Segundo sua Contagem de Células Somáticas. Revista Brasileira de Zootecnia [Internet]. 2000 Dez [cited 2017 Nov 6];29(6):1883-1886. Availaible from: http://dx.doi.org/10.1590/S151635982000000600038. Portuguese.

28. Silva LFP, Pereira AR, Machado PF, Sarriés GA. Efeito do nível de células somáticas sobre os constituintes do leite II - lactose e sólidos totais. Brazilian Journal Veterinary Research and Animal Science [Internet]. 2000 [cited 2017 Nov 6]; 37(4):330-333. Availaible from: https://www.revistas.usp.br/bjvras/article/view/5809/62497. Portuguese.

29. Bueno VFF, Mesquita AJ, Oliveira NA, Nicolau ES, Neves RBS. Contagem bacteriana total do leite: relação com a composição centesimal e período do ano no Estado de Goiás. Revista Brasileira de Ciência Veterinária [Internet]. $2008 \mathrm{Jan} / \mathrm{Abr}$ [cited 2017 Nov 6]; 15(1):40-44. Availaible from: http://doi.editoracubo.com.br/10.4322/rbcv.2014.194. Portuguese. 